\title{
NATURAL AND ORGANIC COSMETICS: DEFINITION AND CONCEPTS
}

\section{Cleber Barros ${ }^{1, *}$, Rosana Bevenuto Guilhen Barros ${ }^{2, *}$}

${ }^{1}$ R\&D Cosmetic Professional, Cosmetology specialist

${ }^{2}$ Pharmacist, Cosmetology specialist

* Vinia Pesquisa e Treinamento, 360 Orosimbo Maia Avenue, Campinas, SP, 13010-211, Brazil. Correspondence: cleber@vinia.digital; Tel.: +55 19 3236-4345

\begin{abstract}
The market of natural and organic cosmetics has been growing in last decades. The increase in interest in this type of product is a consequence of the concern that consumers have been presenting in relation to the environment and health. In addition to the appreciation the use of sustainable ingredients in cosmetic formulations, the consumers are also concerned about pollution caused by the use of plastics, which leads industries to reinvent themselves and rethink about the composition of packaging. The factor that most drives the purchase of natural and organic cosmetics is the fact that the consumer, in addition to contributing to the preservation of the environment, is also using a sustainable product. The growing demand for natural and organic cosmetics results in a concern of the brands with the organic issue, with the decreased use of animal derived ingredients and with the updating the parameters required for certification of a cosmetic as natural or organic. Due to the few studies available in this area, the importance of clarifying the definitions and concepts of natural and organic cosmetics is evident, in order to contribute with accurate information for the cosmetic sector.
\end{abstract}

\section{Key words:}

Natural cosmetics, organic cosmetics, green cosmetics, cosmetology, certification.

\section{INTRODUCTION}

The use of natural cosmetics is growing among the population. Beauty products considered as natural bring an approach of association between the environment preservation and health protection. Thus, consumers of that kind of 
cosmetic search for products with the guarantee that they are really natural. (TOZZO, BERTONCELLO, BENDER, 2012).

Nowadays, the certification of organic cosmetics according to the law $10.831 / 2003$ (brazilian organic regulation) is undefined. The specific Normative Instruction has not yet been published by MAPA (Ministry of Agriculture, Livestock and Food Supply) or ANVISA (Brazilian National Health Surveillance Agency). Therefore, a way of dealing with this scenario is follow the orientations passed by renowned products certifiers. According to some certifying references such as NATRUE and COSMOS-standard, natural cosmetics are defined as products that take in account, during its manufacturing process and life cycle, some points as: use raw materials and methods of production considered more sustainable, work with smaller amounts of ingredients (minimalism) and preserve the safety of their use while becoming less harmful to the environment, in addiction to have a recyclable packaging. (BRASIL, 2003; FONSECA-SANTOS et al., 2015; COSMOS-standard, 2019; NATRUE, 2019).

Seen this, we have a consumer profile that becomes increasingly demanding in relation to this matter. This type of consumer has been around for a long time, but it had its boom a few decades ago. They are consumers who care about the environment and biodiversity, and who do not accept that their products are tested on animals and, for these reasons, agree to buy more expensive products, as long at they meet all these requirements. (FONSECA-SANTOS et al., 2015).

\section{OBJECTIVE}

Define what natural and organic cosmetics are and the main concepts about this topic.

\section{METHODS}

The present research was performed by literature review, searching for scientific articles in databases such as PubMed, Scholar Google and Scielo. For the online research, specific terms such as natural cosmetics, green cosmetics and organic cosmetics were used. In addition, the literature review was also carried out on books, magazines, related sites and certifiers of natural and organic products. 


\section{DISCUSSION}

\section{Concepts}

The relevance in the formulation of natural and organic cosmetics is involved not only in the treatment of skin itself, but also aims the quality of life that the consumer will have when choosing to use a natural cosmetic instead of a conventional cosmetic. Owing to the high variety of ingredients considered as naturals that can be used safely in final cosmetic products, this study area is very promising. (CAVINATO, M. et al., 2017).

Products considered as natural tend to have green characteristics, due to the fact that consumers are concerned not only with the final product they will use, but also with the entire production process, such as recyclable packaging and consistent use of natural resources, for example. Furthermore, the process by which the raw material is obtained is also taken into consideration (use of technologies considered less aggressive to the environment). (FONSECA-SANTOS et al., 2015, IBD, 2019).

As stated by IFOAM (International Federation of Organic Agriculture Movements), ingredients with organic certification are natural substances and derived natural substances from controlled organic farming certified by a duly recognized certification body. (IFOAM, 2018; NATRUE, 2019).

It can be said that in the last two decades the number of studies that prove the benefits of using natural ingredients has increased, both in cosmetics for dermatologic and hair care and for the treatment of diseases. For example, has been proved that colloidal oatmeal promotes better treatment of psoriasis and aloe vera has benefits in treatments of atopic dermatitis. In the case of stain reduction, it was shown that licorice, green tea, arbutin, soy, açai berry, turmeric and pomegranate offer benefits in reducing hyperpigmentation due to its antioxidative action. (JR, F. J. et al., 2010).

The concept of natural and organic cosmetic ingredients is constantly expanding, since both the new consumers and climate changes occurring in the world claims for more sustainability, welfare and animal protection. Observing trends for the future, there is a lot of coherence in wanting to find means of production that is less aggressive to the environment and animals, such as greater responsibility for 
the use of water, increase in the production of sustainable packaging, not conducting tests on animals, dedication to environment, social responsibility and the appreciation of local producers. (ABIHPEC/SEBRAE, 2019/2020).

\section{Cosmetic History}

The cosmetic history occurs along with the evolution of the civilized world, and its use dates back at least 30 thousand years, when cosmetics were used only with religious purposes (like burning of incenses, resins and scented woods) and also to improve the appearance of the body (living or dead). Thus, it is possible to identify that men has always had a bond with cosmetics that has been improving every moment. (SCHLOSSMAN, 2000; CIC, 2010).

\subsection{Egyptians}

According to recording data from the time of Cleopatra, the use of cosmetics started in Egypt, where the queen used to be immersed in goat's milk in order to make her skin softer. Ingredients such as honey, milk, vegetal flours and beeswax were commonly used by the Egyptian people, with which they were manufactured skin creams. In the production of makeup, were used natural lead carbonate and mercuric sulfide, and mixtures of ground charcoal and lead sulfide. And in the case of hair dyes, the Egyptians developed them using henna, roasted gallnuts and iron chips. (SCHLOSSMAN, 2000; SEBRAE/ESPM, 2008).

\subsection{Romans and Greeks}

Through the teachings that the Egyptians passed on, the Roman and Greek peoples also had a strong influence on the history of cosmetics. Hippocrates (considered as the father of medicine), structured all the knowledge he received and started the study of dermatology. Around $400 \mathrm{BC}$. clay cosmetics were already used in Greece, known as "beauty masks". In Rome, a doctor called Galeno (who passed away in $200 \mathrm{AD}$ ), besides transcribing anatomy, pharmacy and pathology subjects, also contributed to the advancement of cosmetology with his formula "cooling ointment", or cold cream emulsion. (SCHLOSSMAN, 2000; CIC, 2010).

In this period, the extracted ingredients were perfumed, such as anise, 
pepper, rosemary, sage, peppermint and lemon balm. Around this same time, perfume shops also started to appear, selling solid unguents, oily liquids and powders. (SCHLOSSMAN, 2000).

\subsection{Ancient East}

In the Middle Ages, after the fall of Rome, the barbarians took over power and the christianity condemned the praise of beauty. In this way, medicine and cosmetology were left out for two centuries. However, men traveling to and from China, India, Tibet and Japan began to spread their acquired knowledge to the East people. Thus, the use of cosmetics continued to happen, although less intensely. (SCHLOSSMAN, 2000; CIC 2010).

During the $3 r d$ to 5 th centuries $A D$ many types of cosmetics were used in India, such as creams, oils, makeup and hair dyes. Even then, cosmetics were correlated with medicine, and started to be used in the treatment of skin diseases. (SCHLOSSMAN, 2000).

\subsection{Renaissance Period}

During the 13th to 16th centuries, Europe has returned to focus on civilization and with the increase in negotiations and trades, there was a significant development in materials related to cosmetics and perfumery. At that time, many materials were brought from the East, such as dyewoods, asbestos, zinc oxide, petroleum, spices, new colors and the use of coal as fuel. (SCHLOSSMAN, 2000).

During the Renaissance Period, in France a Venetian method was used to bleach hair, which consisted of immersing it in soda or alum (sulfate with astringent properties) and letting it dry in the sun. In England, basic lead carbonate (a white powder) was used by people as face powder as a sign of nobility. (SCHLOSSMAN, 2000; CIC, 2010).

In this period, knowledges about alcohol and distillation mechanisms advanced. In the 14th century, the first use of alcohol in perfumes was authenticated when a tincture of rosemary toilet water recipe was published. The attention that was given to the production of perfumes occurred because, despite all the interests with cosmetics and beauty, the habit of not taking a shower still persisted. 
(SCHLOSSMAN, 2000; CIC, 2010).

\subsection{Modern Age}

Distillation methods and procedures were developed, giving rise to essential oils, fats, soaps, and other ingredients used in cosmetics. At that time the cosmetics were made mostly in the home, although the number of outside cosmetic stores was already expanding ceaselessly. In France, the cosmetic market had already grown exponentially with the use of ointments, oils, depilatories and aromatic waters, in addition to everything related to perfumery. (SCHLOSSMAN, 2000; CIC, 2010).

Soap was already manufactured at that time, but subject to high excise taxes, which shows how elegant clothes and hairstyles were still considered more important than basic hygiene, that is, the habit of not taking a shower still existed. At the time, people used an almond paste just to perform a superficial cleansing on the skin. (SCHLOSSMAN, 2000).

\subsection{Contemporary Age}

In the England and the USA, for most of the 19th century, women who wore makeup (except when on stage) were looked upon immoral. Unlike France, where women used cosmetics and makeup long ago. It was only after the First World War that prejudice against the use of cosmetic by Anglo-Americans began to diminish. After World War II, the act of dyeing hair to disguise grey hair spread even more, allowing the growth of the hair coloring industry. (SCHLOSSMAN, 2000).

Reports of the use of sunscreen dates from World War II, when a physical blocker (red petrolatum) was issued by servicemen. The first sale of a sunscreen occurred in the United States, in 1928, and its active ingredients were benzyl cinnamate and benzyl salicylate. (SCHLOSSMAN, 2000).

In the 20th century the most developed countries grew extraordinarily with the production of cosmetics and cosmetics ingredients. Thus, the first cosmetic industries emerged, becoming an important economic agent. (CIC, 2010; SEBRAE/ESPM, 2008). 
Technological advances in cosmetology were too fast and admirable. In the 1980s and 1990s a large use of alpha-hydroxy acids (AHAs) was started in several cosmetic vehicles, as they help to reduce the appearance or lessing of wrinkles and age spots. Among other ingredients that have also started to be commonly used to combat skin aging are enzymes, vitamins and antioxidants. (SCHLOSSMAN, 2000; CIC, 2010).

Regarding the concern with the preservation of the environment and protection of health, it is possible to to highlight the attention and care with the conservation of natural sources of chemical products, biodegradable or reusable packaging, as well as the treatment of waste generated. (CIC, 2010).

\section{A brief history of the beginning of the natural movement}

In 1962, with the publication of the book "Silent Spring" by Rachel Carson, a debate began in the United States about the use of chemical pesticides, as well the responsibility of science and the limits of technological progress, which prompted the awakening of public environmental awareness. This publication raised certain questions to the government, which consented to the deliberate exposure of human beings to toxic substances that were released into the environment. There was no control over the amount of pesticides that were spread throughout the environment, as well as over the levels of exposure of living beings, which could not be measured either. Thus, there was no way to calculate the damage from long-term exposure. (Carson, 1962).

Many manifestations about environmental awareness have occurred, but the decrease in the use of pesticides has not happened in the desired and necessary way to guarantee the safety of living beings. Thus, pollution has ceased to be a theory a long time ago and is a reality of modern life, so that it is necessary to reassess the relationship between the population and the natural world. (Carson, 1962).

According to Carson (1962), what is of most concern is the contamination of air, soil, rivers and seas, which in most cases is irrecoverable. This contamination, caused mainly by synthetic ingredients that are increasingly innovative. Thus, it becomes necessary to establish a control over the resources that are used in the 
production of synthetic ingredients and in the use of pesticides for pest prevention, associated with the modern lifestyle.

\section{Cosmetic legislation}

According to RDC resolution $\mathrm{n}^{\circ} 07$ of February 2015 (Brazil), cosmetics, perfumes and personal hygiene products are "preparations made up of natural or synthetic substances, for external use in the different parts of the human body, skin, capillary system, nails, lips, genitals external, teeth and mucous membranes of the oral cavity, with the exclusive or main objective of cleaning, perfuming, altering their appearance and or correcting body odors and either protecting or maintaining them in good condition". In addition, cosmetic products must follow some other rules, which provide for which substances are or are not allowed, such as preservative substances, dyes and ultraviolet filters. (ANVISA, 2015).

\section{Regularization of natural and organic cosmetic products}

Currently, there are no general rules dealing with the definition of natural or organic cosmetics. As there are no official norms and legal bases for the characterization of these types of products, one way of being able to use the terms as "natural" and "organic" for cosmetic products is to stick to the guidelines of some certifying references, such as NATRUE and COSMOS-standard. First of all, natural and organic cosmetics are defined as cosmetic products and, therefore, they must meet the standards of the RDC $n^{\circ} 07$ of February 10, 2015 (Brazil), or the standards in force in the country of origin that provides the technical requirements for the regularization of cosmetic products, and therefore must meet the requirements of composition, safety, effectiveness and labeling. Only after following the basic requirements in force in the country the product is able to be classify as natural and organic, through the adoption of what the certifiers preach. (SEBRAE, 2012; ANVISA, 2015; NATRUE, 2019).

\section{Certifying (NATRUE and COSMOS-standard)}

6.1 NATRUE and IBD 
The certifier NATRUE (The International Natural and Organic Cosmetics Association) is an international non-profit association that works promoting and disseminating concepts and practices about natural and organic cosmetics. Its main objectives are to create requirements for the definition and characterization of cosmetic and organic products and to combat the practice of Greenwashing (term used to define a model of advertising that use the idea of sustainability just by marketing strategy to attract the consumer attention) and misleading claims on market products. This guideline has three categories of certification for finished products, which must follow some requirements regarding the concentration of natural substances, derived natural substances and the minimum content of organic ingredients contained in the product. (NATRUE, 2019; De JONG, HARKINK e BARTH, 2017).

Each product category has a different label, informing which is the certification category. According to NATRUE, the certifications categories are: natural cosmetic, natural cosmetic with organic portion and organic cosmetic. Thus, the certifier also defines 13 categories of cosmetic formulations that can be certified, according to the established rules. Each category has specific rules regarding the concentration of natural substances and derived natural substances that it must contain. (NATRUE, 2019).

In addition, NATRUE signed an agreement on criteria for certification of organic and natural products with IBD (Instituto Biodinâmico, Brazil). IBD is a certifier of organic products present in Latin America, and has accreditation with IFOAM (The International Federation of Organic Agriculture Movements), ISO/IEC 17065 (European market-regulation CE 834/2007), Demeter (international market), USDA/NOP (North American market) and approved for use of the SISORG (Brazilian Organic Conformity Assessment System), which makes the certificate accepted globally. Thus, NATRUE and IBD have international equivalence requirements, with mutual recognition of standards alignment. (IBD, 2014; NATRUE, 2019).

\subsubsection{Natural cosmetics}


According to NATRUE, for a cosmetic to be considered as natural and to be certified as such, it must contain a minimum level of natural substances and a maximum level of derived natural substances, as shown in table 2 (NATRUE, 2019).

\subsubsection{Natural cosmetics with an organic portion}

For natural cosmetics with an organic portion, they must contain a minimum level of natural substances with organic certification and a maximum level of substances derived from natural, in which their production (their primary ingredient) is from organic origin. So that at least $70 \%$ of these substances must have organic certification or be from wild collection. In the case of derived natural substances that have been produced from certified ingredients, the content of the organic portion will be considered and added to the organic total amount, as shown in table 3 (NATRUE, 2019).

\subsubsection{Organic cosmetics}

In the case of organic cosmetics, they must also contain a minimum level of natural substances and a maximum level of substances derived from natural, in which their production (their primary ingredient) is from organic origin. However, at least $95 \%$ of the natural substances of plants and animal origin and of derived natural substances contained in the product must have organic certification or be from wild collection. In case of derived natural substances that have been produced from certified organic ingredients, the content of the organic amount will be considered and added to the organic total amount, as shown in table 4 (NATRUE, 2019).

\subsubsection{Permitted ingredients categories}

There are three categories of permitted ingredients for use in cosmetics, according to the NATRUE guideline: natural substances, derived natural substances and nature-identical substances. (NATRUE, 2019).

\subsubsection{Natural substances}

Natural substances are substances of botanic, inorganic-mineral or animal origin (with the exception of dead vertebrates) and mixtures of these substances that 
have undergone physical processes for their extraction, that is, that do not cause changes in the natural component, such as essential oils, vegetable oils and extracts (NATRUE, 2019).

According to the NATRUE guidelines, water will be considered a natural substance only when it is in accordance with that shown in table 1. Depending on the ingredient used, only a few parts are considered natural. The table 1 shows the specification of ingredients parts that are considered natural.

\begin{tabular}{|c|c|}
\hline Type of ingredient & What is considered natural \\
\hline Vegetable juices & $100 \%$ from vegetable juice \\
\hline Concentrated vegetable juices & $\begin{array}{c}\text { Only the juice, without the water } \\
\text { used for dilution }\end{array}$ \\
\hline Aqueous extracts & Only the plant portion \\
\hline Hydroalcoholic extracts & $\begin{array}{c}\text { Only the plant and alcohol } \\
\text { portions (if this is a natural } \\
\text { substance) }\end{array}$ \\
\hline
\end{tabular}

Table 1 Specification of ingredients parts that are considered natural.

Source: NATRUE, 2019.

\subsubsection{Nature-identical substances}

Nature-identical substances may only be used when a natural option is impossible. Examples of natural-identical substances are some inorganic pigments, minerals and preservatives(NATRUE, 2019).

\subsubsection{Derived substances}

Derived substances are the raw materials subjected to processes that cause little change in the natural component and follow the permitted reactions. They can be used only when the function cannot be performed using a natural substance. These substances are obtained from natural substances, such as fats, oils, waxes, polysaccharides, proteins and lipoproteins. However, there are a limited number of chemical reactions accepted in the production of this type of ingredient. Besides that, the the raw materials of this class must, necessarily, be produced through processes modelled on physiological mechanisms, and should pass through the fewest 
conversion steps as possible. For this type of raw material, only the following chemical reactions are permitted: acylation, amidation, condensation (with elimination of water), dehydrogenation, dimerization, esterification, glycosidation, hydrogenation, hydrogenolysis, hydrolysis (including saponification), neutralisation, oxidation (with oxygen, ozone and peroxides), phosphorylation, pyrolysis, sulphatation and transesterification. Among the prohibited reactions are: ethoxylation, propoxylation, sulfonation, phosphating, polymerization (NATRUE, 2019; IBD, 2014).

For each of the three categories of finished products, there are stipulated levels of these substances for different types of cosmetic products, such as emulsions, sunscreens, soaps, among others. This specification is shown in the figures below:

\begin{tabular}{|c|c|c|c|c|c|c|c|c|c|c|c|c|c|}
\hline & $1^{* * *}$ & 2 & 3 & 4 & 5 & 6 & 7 & 8 & 9 & 10 & $11^{\star \star \star \star}$ & 12 & 13 \\
\hline 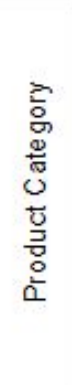 & 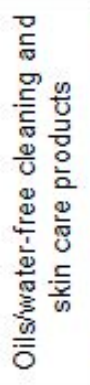 & 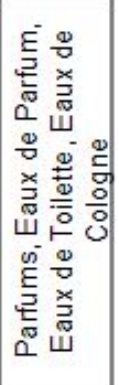 & 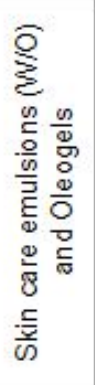 & 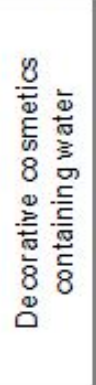 & 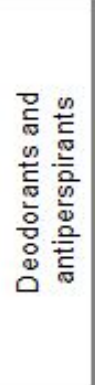 & 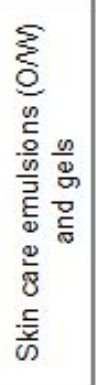 & 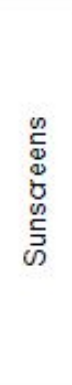 & 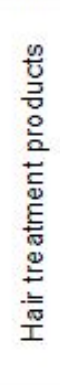 & 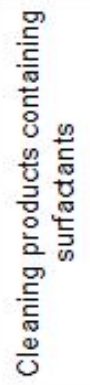 & $\frac{\frac{\Phi}{8}}{\frac{8}{6}}$ & 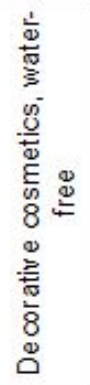 & $\begin{array}{l}\mathscr{0} \\
\stackrel{0}{\circ} \\
\stackrel{\circ}{1}\end{array}$ & $\frac{\frac{\omega}{\omega}}{\stackrel{5}{\leftrightarrows}}$ \\
\hline \multirow{3}{*}{ 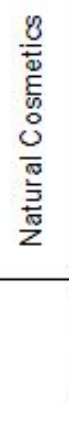 } & 80 & 60 & 30 & 10 & 10 & 10 & 10 & 3 & 3 & 2 & 1 & 1 & 0,1 \\
\hline & 20 & 10 & 30 & 30 & 30 & 25 & 55 & 40 & 85 & 70 & 50 & 99 & 10 \\
\hline & 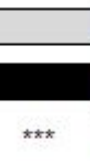 & $\begin{array}{l}\text { Minim } \\
\text { Maxim } \\
\text { Water- }\end{array}$ & onte & nat & subs & $\begin{array}{l}\text { ces } \\
\text { sub } \\
\text { up }\end{array}$ & $\begin{array}{l}\text { es } \\
\%\end{array}$ & 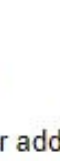 & & & & & \\
\hline
\end{tabular}

Figure 1 Specification of the minimum concentration of natural substance and the maximum concentration of natural substance derived in natural cosmetics.

Source: Adapted from NATRUE, 2019. 


\begin{tabular}{|c|c|c|c|c|c|c|c|c|c|c|c|c|c|}
\hline & $1^{* \star * *}$ & 2 & 3 & 4 & 5 & 6 & 7 & 8 & 9 & 10 & $11^{x * x}$ & 12 & 13 \\
\hline 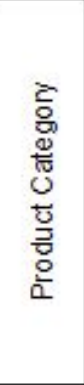 & 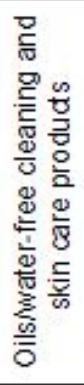 & 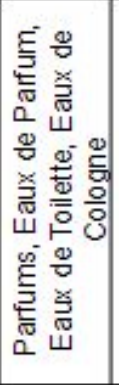 & 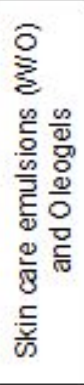 & 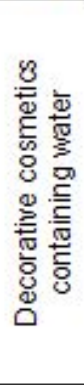 & 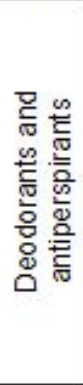 & 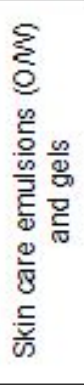 & 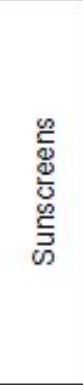 & 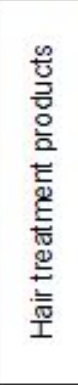 & 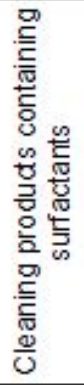 & 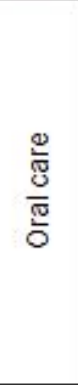 & 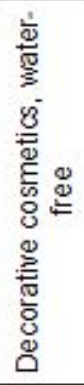 & 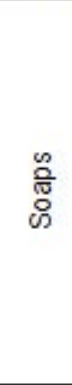 & 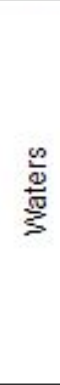 \\
\hline \multirow{3}{*}{ 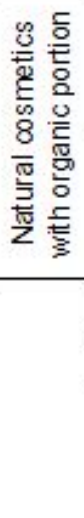 } & $90^{*}$ & $60^{*}$ & $30^{*}$ & $15^{*}$ & $15^{*}$ & $15^{*}$ & $15^{*}$ & $15^{*}$ & $15^{\star}$ & $15^{*}$ & $15^{*}$ & $1^{*}$ & $15^{*}$ \\
\hline & $10^{* *}$ & $10^{\star \star *}$ & $20^{* *}$ & $15^{* *}$ & $15^{\star \star}$ & $20^{\star \star}$ & $30^{\star *}$ & $15^{* *}$ & $25^{* *}$ & $15^{\star * t}$ & $15^{\star \star}$ & $99^{\star *}$ & $5^{\star * t}$ \\
\hline & $\underset{* * *}{\star}$ & \multicolumn{12}{|c|}{$\begin{array}{l}\text { Additional requirements on the content of natural oraanic substances. } \\
\text { Additional requirements on the content of natural substances derived }\end{array}$} \\
\hline
\end{tabular}

Figure 2 Specification of the minimum concentration of natural substance and the maximum concentration of natural substance derived in natural cosmetics with organic portion.

Source: Adapted from NATRUE, 2019.

\begin{tabular}{|c|c|c|c|c|c|c|c|c|c|c|c|c|c|}
\hline & $1^{* \pi *}$ & 2 & 3 & 4 & 5 & 6 & 7 & 8 & 9 & 10 & $11^{* * * x}$ & 12 & 13 \\
\hline 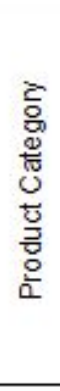 & 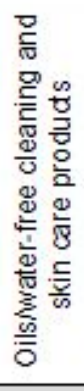 & 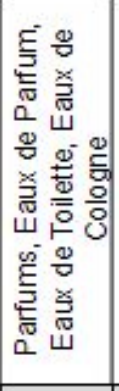 & 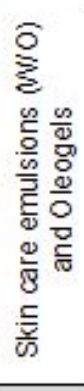 & 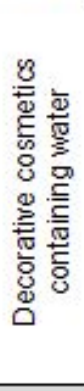 & 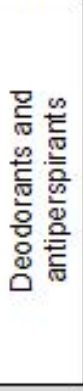 & 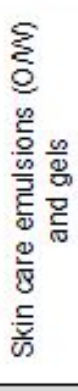 & 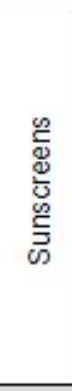 & 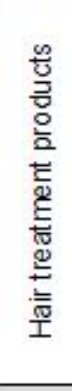 & 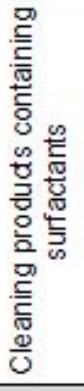 & 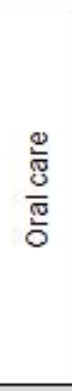 & 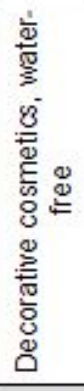 & 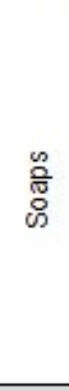 & $\frac{\frac{\omega}{2}}{\frac{N}{5}}$ \\
\hline \multirow{3}{*}{ 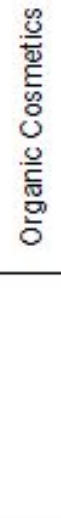 } & $90^{*}$ & $60^{*}$ & $30^{*}$ & $20^{*}$ & $20^{*}$ & $20^{*}$ & $20^{*}$ & $20^{*}$ & $20^{*}$ & $20^{*}$ & $20^{*}$ & $1^{*}$ & $20^{*}$ \\
\hline & $10^{\star t *}$ & $10^{\star \pm}$ & $15^{\star \star \star}$ & $15^{* t}$ & $15^{\star \star}$ & $15^{\star *}$ & $15^{\star *}$ & $15^{\star \star t}$ & $25^{\text {t*t}}$ & $15^{\text {t*t}}$ & $15^{\star \star}$ & $99^{\star *}$ & $5^{* *}$ \\
\hline & $\begin{array}{l}* \\
\star * \\
* * *\end{array}$ & $\begin{array}{l}\text { Minimum } \\
\text { Maximur } \\
\text { Additiona } \\
\text { Additiona } \\
\text { Water-fre }\end{array}$ & $\begin{array}{l}\text { conten } \\
\text { conte } \\
\text { I reauir }\end{array}$ & $\begin{array}{l}\text { f natur } \\
\text { of deriv } \\
\text { nents }\end{array}$ & $\begin{array}{l}\text { substa } \\
\text { d natur } \\
\text { the cor }\end{array}$ & $\begin{array}{l}\text { I ces ( } 9 \\
\text { subst } \\
\text { ent of }\end{array}$ & $\begin{array}{l}\operatorname{ces} 11^{\circ} \\
\text { tural }\end{array}$ & anic $s$ & stances & 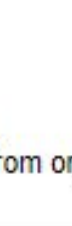 & . & & \\
\hline
\end{tabular}

Figure 3 Specification of the minimum concentration of natural substance and the maximum concentration of natural substance derived in organic cosmetics.

Source: Adapted from NATRUE, 2019 


\subsubsection{Prohibited ingredients}

According to IBD, some ingredients should not be used in finished products, be they natural, organic or with an organic portion. Such ingredients are: polyethylene glycols (PEGs), silicones, quaternary ammonium, diethanolamides, petroleum derivatives, genetically modified organisms (OMG), fragrances, dyes and synthetic preservatives. (IBD, 2014).

\subsubsection{Packaging}

As stated by NATRUE, in addition to presenting the smallest size as possible, the packaging of natural, organic and natural cosmetic products with an organic portion should preferably be made of recyclable materials, such as glass, aluminium, paper/cardboard and/or recyclable plastics. Furthermore, products must be designed for multiple uses (except for sample packs). The permitted propellants are air, nitrogen, oxygen carbon dioxide, argon (but without volatile organic compounds). Gases will not be taken into account for calculations and halogenated plastics (such as polyvinyl chloride and chlorinated plastics) may not be used in packaging for these products (NATRUE, 2019).

\subsubsection{General NATRUE labeling and certification rules}

For the cosmetic product line to be able to bear the certification label, it must have certification of at least $75 \%$ of products of a specific brand (or sub-brand). If there are products certified by another certifying standard, they can be counted in the calculation of $75 \%$, to obtain NATRUE certification. However, this accounting will only be allowed during the first two years of the certificate. After this period, the brand must have a threshold of $75 \%$ of the products in the line with NATRUE certification. Double labelling is permitted as long as the above requirements are met (NATRUE, 2019).

6.2 COSMOS-standard (BDIH, Cosmebio, Ecocert, ICEA and Soil Association)

COSMOS-standard is an international non-profit association created to promote and disseminate concepts and practices about natural and organic 
cosmetics. It is formed by the union of five organizations in Europe, namely: BDIH (Germany), Cosmebio (France), Ecocert (France), ICEA (Italy) and Soil Association (United Kingdom). Furthermore, its main objectives are promoting the use of products from organic agriculture and respecting biodiversity, using natural resources responsibly, and respecting the environment, using safe and respectful production processes for human health and the environment and strengthen the concept of "Green Chemistry". This guideline has two types of certification for finished products: natural cosmetics and organic cosmetics (COSMOS, 2019).

\subsubsection{Natural cosmetics}

According to COSMOS there is no requirement on a minimum concentration of organic content that should be used in formulations certified as natural, however, there is a calculation rule for determining the concentration of ingredients of natural origin in cosmetic products (COSMOS-standard, 2019):

$\%$ natural origin of total $=$ [weight of total product - weight of non-natural origin ingredients - weight of petrochemical moieties] / weight of all ingredients $\times 100$

\subsubsection{Organic cosmetics}

For organic cosmetics, the general rule is that at least $95 \%$ of the physically processed agro-ingredients must be organic. The remaining physically processed agro-ingredients must be organic and certified only if they are present on the list issued by the certifier. In the final product, at least $20 \%$ of the total product must be organic. (COSMOS-standard, 2019).

Besides to this general rule, there are some specific requirements for certain products (COSMOS-standard, 2019):

- Soaps, alcohol spritzers and perfumes: they are formulations with a high concentration of chemically processed ingredients. Therefore, it is not possible to meet the requirement of at least $95 \%$ of physically processed and organic ingredients.

- Alcohol spritzers and perfumes: at least $95 \%$ of the physically processed ingredients must be organic.

- Soaps created by saponification: when created from simple raw materials 
(vegetable oils, butters, etc.), at least $95 \%$ of the physically processed ingredients must be organic.

- Soaps created from noodles and other ingredients: at least $95 \%$ of physically processed and chemically processed ingredients must be organic.

Furthermore, as for the final product, there are some exceptions to the concentration: rinse-off products, non-emulsified aqueous products, and products with at least $80 \%$ minerals or ingredients of mineral origin must have at least $10 \%$ of the total formulation ingredients as being organic (COSMOS, 2019).

\subsubsection{Categories of allowed ingredients}

To facilitate the understanding of the proposed rules, COSMOS-standard specifies five categories of ingredients contained in a cosmetic product. According to the increasing order of human intervention, they are: water, mineral ingredients, physically processed agro-ingredients, chemically processed agro-ingredients and other ingredients (COSMOS-standard, 2019).

\subsubsection{Water}

Water is the basic ingredient of the formulation, therefore, its quality level is essential, and must be treated with permitted physical processes. Potable water, spring water, water obtained by osmosis, distilled water or sea water can be used (COSMOS-standard, 2019).

\subsubsection{Mineral ingredients}

Minerals and ingredients of mineral origin are important but are not renewable, so there are environmental rules on their use. Thus, minerals may be used as long as they are obtained from environmentally sound extraction processes and without intentional chemical modification (COSMOS-standard, 2019).

\subsubsection{Physically processed ingredients}

This category includes substances of plant, animal or microbial origin subjected to physical processes. These ingredients can only be used if they are extracted through permitted physical processes. In addition, ingredients of animal 
origin must not entail the death of the animal concerned and can be produced by animals, but without being part of them. Also, the ingredients must comply with the requirements of the International Trade in Endangered Species of Wild Fauna and Flora (CITES), and the use of Genetically Modified Organisms (GMOs) and primary raw materials extracted from living or slaughtered animals is forbidden. Finally, the ingredients must be obtained using natural materials with any forms of water or a vegetable solvent which can be ethyl alcohol, glycerine, vegetable oils, honey or supercritical carbon dioxide (COSMOS-standard, 2019).

\subsubsection{Chemically processed ingredients}

This category includes substances of plant, animal or microbial origin submitted to chemical processes. For its extraction, organic raw materials and permitted processes must be considered clean and follow the principles of green chemistry (Environmental Protection Agency Green Chemistry Programme, USA). The use of OMG and primary raw materials extracted from living or slaughtered animals is forbidden.(COSMOS-standard, 2019).

\subsubsection{Others ingredients}

The use of certain other ingredients is allowed only if there are no effective natural alternatives available to ensure the safety of the consumers or efficacy of the product. For this, it is necessary to obey the options that are provided as preservatives, solvents, ingredients that contain in their composition petrochemical and natural moieties, among others (COSMOS-standard, 2019).

\subsubsection{Allowed processes}

COSMOS-standard defines which physical and chemical processes can be used, as well as which are prohibited.

\subsubsection{Physical processes allowed}

Only processes that respect the natural active substances present in ingredients are allowed, in addition to respecting the ecological balance, energy use and waste management. The permitted physical processes are: deodorisation, 
mixtures, centrifugation, extraction, pressure, decoction, drying (by evaporation), deterpenation (if fractionated distillation with steam), distillation (only by steam), filtration and purification (ultra filtration, dialysis, crystallisation and ion exchange), decoloration (only these decolorizing agents are allowed: bentonite, activated charcoal, bleaching earth, hydrogen peroxides and ozone), freezing, grinding, infusion, lyophilization, maceration, microwave, percolation, roasting, decanting, sifting, sterilisation by means of UV, sterilisation with thermal treatments (the temperature must respect the active substances), ultrasound, UV treatments and vacuum. (COSMOS-standard, 2019).

\subsubsection{Chemical processes allowed}

These are the processes which allow the formation of biodegradable molecules. Only processes that respect the natural active substances present in ingredients are allowed, in addition to respecting ecological balance, energy use and waste management. The permitted chemical processes are: alkylation, amidation, biotechnology processes, calcination of plants residues, carbonization (resins and organic fatty oils), condensation and addition, esterification, trans-esterification, inter-esterification, etherification, hydration, hydrogenation, hydrolysis, ionic exchange, neutralization, oxydization and reduction, phosphorylation (permitted only for ingredients for leave-on products), saponification and sulphation (COSMOS-standard, 2019).

\subsubsection{Not allowed processes}

According to COSMOS-standard, the following physical and chemical processes are prohibited: alkoxylation (including ethoxylation and propoxylation) using ethylene oxide, propylene oxide or other alkylene oxides, bleaching and deodourisation (on a support of animal origin), deterpenation (except with steam), halogenation (as main reaction), ionising radiation, sulphonation (as the main reaction), treatments with ethylene oxides and treatments using mercury (COSMOS-standard, 2019). 
To carry out the certification of cosmetic ingredients or natural or organic cosmetic products, it is required to fulfil the requirements of the certification standards. After a on-site inspection and verification of the ingredients and final products validation, the certification is issued. In the case of using non-organic cosmetic ingredients, approval is required. In view of this, a documentary validation is carried out without on-site inspection. This approval only states that a certain non-organic ingredient is acceptable to be used. In addition, the bodies certifying to this Standard must be associate members of COSMOS-standard (COSMOS-standard, 2019)

\subsubsection{Packaging}

The packaging must be made of recycled materials whenever possible, besides complying with the list of specific materials that are accepted by the certifier. Use as little material as possible and increase the amount of material that can be recycled. Some materials are forbidden, such as polyvinyl chloride (PVC), plastics containing styrene, materials that contain, have been derived from, or manufactured using OMG, and part of animals or substances produced by animals, such as leather and silk for example. Whereas, among the permitted materials are cellulose, ceramic, glass, paper/cardboard, rubber (from natural origin), wood, among others (COSMOS-standard, 2019).

\subsubsection{General labelling rules}

As stated by COSMOS-standard, the labeling and communication of the product must be clear, so as not to mislead the consumer. There are some differences in the rules between products with organic certification and products with natural certification (COSMOS-standard, 2019).

\subsubsection{For products with organic certification}

The labels on the packaging of products with organic certification must necessarily have the following characteristics: have the signature "COSMOS ORGANIC" as a reference added to the label of the member organization COSMOS-standard AISBL; indicate the certifying body; indicate (by weight) the 
percentage of organic origin ingredients in the total product; indicate (by weight) the percentage of organic origin ingredients in the total product without water and minerals; indicate (by weight) the percentage of natural origin ingredients in the total product; indicate organic ingredients and those made from organic raw materials in the INCl list - which corresponds to the sentences: "from organic agriculture" for physically processed agro-ingredients and "made using organic ingredients" for chemically processed agro-ingredients (COSMOS-standard, 2019).

Furthermore, the term "organic" should not be assigned to the final product, unless it is at least 95\% organic (assessed as a percentage of the total product). For products that are $100 \%$ organic or $100 \%$ natural, the indication of the percentage natural is not obligatory (COSMOS-standard, 2019).

\subsubsection{For products with natural certification}

The labels on the packaging of products with natural certification must necessarily have the following characteristics: have the signature "COSMOS NATURAL" as a reference added to the label of the member organization COSMOS-standard AISBL; indicate the certifying body; indicate (by weight) the percentage of natural origin ingredients in the total product; indicate (by weight) the percentage of natural origin ingredients in the total product without water and minerals; indicate (by weight) the percentage of natural origin ingredients in the total product; indicate natural ingredients and those made from organic raw materials in the $\mathrm{INCl}$ - which corresponds to the sentences: "from organic agriculture" for physically processed agro-ingredients and "made using organic ingredients" for chemically processed agro-ingredients (COSMOS-standard, 2019 ).

Furthermore, organic quotes on the packaging are restricted to the organic content of the total product and the organic ingredient(s) in question. For products that are $100 \%$ natural, the indication of the percentage natural is not obligatory (COSMOS-standard, 2019).

\subsection{Main differences between NATRUE and COSMOS-standard certifiers}

The two main certifiers of natural and organic cosmetic products have some differences in their main characteristics, regarding certification categories, allowed 
ingredient categories, lists of natural ingredients that must have organic certification, positive list of chemically processed ingredients and the minimum number of branded products that need to be certified. Below is a brief comparison between the main characteristics of the NATRUE and COSMOS-standard certifiers (NATRUE, 2019; COSMOS-standard, 2019). The table 2 shows the comparison between the main differences of the NATRUE and COSMOS-standard certifiers.

\begin{tabular}{|c|c|c|}
\hline & \multicolumn{2}{|c|}{ CERTIFYING } \\
\hline & NATRUE & cosMOS-standard \\
\hline $\begin{array}{l}\text { Certification } \\
\text { categories }\end{array}$ & $\begin{array}{l}\text { - Natural cosmetics } \\
\text { - Natural cosmetics with an } \\
\text { organic portion } \\
\text { - Organic cosmetics }\end{array}$ & $\begin{array}{l}\text { - Natural cosmetics } \\
\text { - Organic cosmetics }\end{array}$ \\
\hline $\begin{array}{l}\text { Allowed } \\
\text { ingredient } \\
\text { categories }\end{array}$ & $\begin{array}{l}\text { - Natural substances } \\
\text { - Nature-identical substances } \\
\text { - Derived substances }\end{array}$ & $\begin{array}{l}\text { - Water } \\
\text { - Mineral ingredients } \\
\text { - Physically processed ingredients } \\
\text { - Chemically processed } \\
\text { ingredients } \\
\text { - Other ingredients }\end{array}$ \\
\hline $\begin{array}{l}\text { Positive list of } \\
\text { natural } \\
\text { ingredients } \\
\text { that, if used, } \\
\text { must have } \\
\text { organic } \\
\text { certified }\end{array}$ & Yes & No \\
\hline $\begin{array}{l}\text { Positive list of } \\
\text { chemically } \\
\text { processed } \\
\text { ingredients }\end{array}$ & Yes & No \\
\hline $\begin{array}{l}\text { Minimum } \\
\text { number of } \\
\text { branded } \\
\text { products that } \\
\text { need to be } \\
\text { certification }\end{array}$ & Has requirements & Not specified \\
\hline
\end{tabular}

Table 2 Comparison between the main differences of the NATRUE and COSMOS-standard certifiers. Source: NATRUE, 2019 e COSMOS-standard, 2019. 


\section{Consumer market and media influence}

Nowadays, the cosmetics consumer has a different attitude than the consumer of two decades ago. Today, this consumer is more concerned with preventing damage to the skin than with the subsequent correction of that damage. Moreover, attention is more focused on the initial source of products, thus preferring the most natural options. Furthermore, in most cases, this type of consumer is already aware of the advantages of using this type of product and believes that they should take care of their skin with the same care and delicacy used in creating the cosmetic product they are using (BOWE, 2013; SEBRAE, 2012; SEBRAE / ESPM, 2008).

According to a published article, $74 \%$ of consumers purchase certain products due to the influence of social media. In other words, this new way of purchasing decision power has been shown to be more effective and powerful when compared to television advertisements, for example $\left({ }^{\odot} 2018\right.$ Abril Mídia S A.).

With the natural cosmetics market the scenario is not different. Various societies, organizations and digital influencers inform the consumer of the advantages and benefits of using this type of product, addressing environmental, social and ecological issues, in order to make the population aware of the concern with the environment, sustainability and their own well-being.(SEBRAE, 2012).

The main consumers of the coming years are the so-called Millennials (people who were born between 1980 and the mid-1990s) and Generation Z (people who were born between the end of the 1990s until 2010); that is, they are people who already have, or are acquiring, purchasing power and are at the best age to generate loyalty under some brand. Usually, this type of consumer is always aware of issues related to the environment and the ingredients present in the cosmetic products they use, being more likely to pay more for innovative products (ABIHPEC / SEBRAE, 2019/2020).

Moreover, the increase in the level of education, use of the internet and mobile devices is undeniable, generating information, knowledge and communication between people. Thus, the more informed consumers are, that is, the more aware of ethical and ecological problems, the more they demand from the products they consume, which leads to questions about the origin of the product, how it is produced 
and how this is done and causes impacts on the environment and animals (SAHOTA, 2013).

\section{FINAL CONSIDERATIONS}

Through all the literature review carried out, as well as the consultation of the materials of the certifying companies, it was verified that it is necessary a greater understanding of the consuming public on the definition of natural and organic cosmetics, as well as the raw materials, their respective quantities and the processes that are allowed in the manufacture of each of them.

Furthermore, it is clear that the demand for this type of cosmetic products is gradually increasing, mainly by certain groups of consumers, who are increasingly demanding that companies adopt ingredients and production methods that cause less impact on the environment and animals.

Thus, natural and organic products can be understood as those that have some relevant characteristics, such as: have sustainable attributes, recyclable and returnable packaging, do not have ingredients considered harmful to health by popular classification.

In this work, a wide literature review was made possible, considering the most significant publications for the area, which evaluate the concepts and definitions about natural and organic cosmetics. As shown throughout the work, much was researched and studied on the subject, so that general information was not used, but updated, correct and accurate on the classification of each type of product according to the main certifiers in the world.

The search for knowledge, acquisition and use of natural and organic cosmetics are constantly growing, so the topic is highly relevant and the interest of companies and professionals in the area to update themselves and seek accurate information, in order to offer, transparently, the best for the final consumer. 


\section{REFERENCES}

ABIHPEC - ASSOCIAÇÃO BRASILEIRA DE INDÚSTRIA DE HIGIENE PESSOAL, PERFUMARIA E COSMÉTICOS. Guia Técnico Ambiental da Indústria de Higiene Pessoal, Perfumaria e Cosméticos. São Paulo: 2012b. Disponível em: https://abihpec.org.br/site2019/wp-content/uploads/2012/07/higiene.pdf. Acesso em: 23 jan. 2020.

ABIHPEC; SEBRAE. Caderno de tendências: 2019-2020. 2019.

ANVISA - AGÊNCIA NACIONAL DE VIGILÂNCIA SANITÁRIA. Resolução da Diretoria Colegiada - RDC $n^{\circ}$ 07, de 10 de fevereiro de 2015. Disponível em: http://portal.anvisa.gov.br/documents/10181/2867685/RDC_07_2015_.pdf/c2a1078c46cf-4c4b-888a-092f3058a7c7. Acesso em: 29 jan. 2020.

BRASIL. Lei $n^{\circ} 10.406$, de 23 de dezembro de 2003. Dispõe sobre a agricultura orgânica, e dá outras providências. Diário Oficial da União. Brasília, DF, 23 dez. 2003. Disponível em: https://www.planalto.gov.br/ccivil_03/_ato2007-2010/2007/decreto/d6323.htm. Acesso em: 13 abr. 2020.

CARSON, Rachel; Primavera Silenciosa. 1. ed. São Paulo: Gaia, 1962. p. 9-327.

CAVINATO, Maria et al. Plant extracts and natural compounds used against UVB-induced photoaging. Biogerontology, v. 18, n. 4, p. 449-516, 12 jul. 2017. DOI 10.1007/s10522-017-9715-7. Disponível em: https://link.springer.com/article/10.1007/s10522-017-9715-7. Acesso em: $10 \mathrm{dez}$. 2019.

CIC, Comissão da Indústria Cosmética do CRF/PR. Guia da Profissão Farmacêutica - Indústria de Produtos de Higiene Pessoal, Cosméticos e Perfumes. $\quad 1$ ed., $2010 . \quad$ Disponível em: https://www.crf-pr.org.br/uploads/comissao/6295/Guia_cosmetico.pdf. Acesso em: 20 jan. 2020.

COSMOS. Cosmetics Organic and Natural Standard. Versão 3.0. 2019. Disponivel em: https://www.cosmos-standard.org/about-the-cosmos-standard. Acesso em: 03 fev. 2020.

De JONG, M. D. T.; HARKINK, Karen M.; BARTH, Susanne. Making Green Stuff? 
Effects of Corporate Greenwashing on Consumers. Journal of business and technical communication, United States, v. 32, n. 1, p. 77-112, set./2017. Disponível em: https://www.ncbi.nlm.nih.gov/pmc/articles/PMC6044111/. Acesso em: 12 mai. 2020.

EXAME. Consumo: $\mathbf{7 4 \%}$ das pessoas compram de acordo com as influências das mídias sociais. Disponível em: https://exame.abril.com.br/negocios/dino/consumo-74-das-pessoas-compram-de-aco rdo-com-as-influencias-das-midias-sociais/. Acesso em: 21 jan. 2020.

FISHMAN, Harvey. Cosmetics, Past, Present, Future. In: SCHLOSSMAN, Mitchell. The Chemistry and Manufacture of Cosmetics. 3. ed. USA: Allured Publishing Corporation, 2000. v. 1, cap. 1, p. 1-10. ISBN 0-931710-75-8.

FOWLER, Joseph et al. Innovations in Natural Ingredients and Their Use in Skin Care. Journal of drugs in dermatology, v. 9, n. 6, p. 72-81, 22 jun. 2010. DOI 20626172. Disponível em: https://pubmed.ncbi.nlm.nih.gov/20626172/. Acesso em: 22 jan. 2020.

IBD CERTIFICAÇÕES. DIRETRIZES PARA A CERTIFICAÇÃO DE PRODUTOS DE SAÚDE E BELEZA ORGÂNICOS E NATURAIS E PARA INGREDIENTES ORGÂNICOS E NATURAIS. Botucatu - SP, 5 ed. 2014. Disponível em: https://www.ibd.com.br/wp-content/uploads/2019/09/8_1_2_Diretrizes IBD_Cosmetic os_5aEd_082014_V.pdf. Acesso em: 29 jan. 2020.

IFOAM. THE IFOAM FAMILY OF STANDARDS. Disponível em: https://www.ifoam.bio/pt/ifoam-family-standards-0. Acesso em: 13 abr. 2020.

MINTEL. GLOBAL PACKAGING TRENDS. 2019. Disponível em: https://downloads.mintel.com/private/nlYDR/files/753149/. Acesso em: 03 fev. 2020.

BOWE, Whitney. Cosmetic Benefits of Natural Ingredients: Mushrooms, Feverfew, Tea, and Wheat Complex. Journal of drugs in dermatology: JDD, Brooklyn, NY, v. 12, n. 9, p. 133-136, set./2013. Disponível em: https://jddonline.com/articles/dermatology/S1545961613S0133X/. Acesso em: 10 dez. 2019.

NATRUE. NATRUE Label: requirements to be met by natural and organic cosmetics. Versão 3.8 .2019 .2 Disponível em: https://www.natrue.org/natrues-standard-update-version-3-8-2/. Acesso em: 30 jan. 2020. 
NATRUE. Who We are partners. Disponível em: https://www.natrue.org/who-we-are/our-partners/. Acesso em: 13 abr. 2020.

SAHOTA, Amarjit; Sustainability: How the Cosmetics Industry is Greening up. 1. ed. EUA: John Wiley \& Sons, Ltd., 2013. p. 1-15.

SANTOS, Bruno Fonseca; CORREA, Marcos Antonio; CHORILLI, Marlus. Sustainability, natural and organic cosmetics: consumer, products, efficacy, toxicological and regulatory considerations. Brazilian Journal of Pharmaceutical Sciences, São Paulo, v. 51, n. 1, p. 17-26, mar./ 2015. DOI 10.1590/S1984-82502015000100002. Disponível em: https://www.scielo.br/scielo.php?script=sci_arttext\&pid=S1984-82502015000100017 \&lng=en\&nrm=iso\&tlng=en. Acesso em: 9 dez. 2019.

SEBRAE. Como montar uma fábrica de cosméticos ecológicos. Disponível em: https://www.sebrae.com.br/sites/PortalSebrae/ideias/como-montar-uma-fabrica-de-c osmeticos-ecologicos,22597a51b9105410VgnVCM1000003b74010aRCRD. Acesso em: 21 jan. 2020.

SEBRAE/ESPM. Estudos de mercado. Cosméticos à base de produtos naturais. Relatório completo. Série mercado, 2008.

TOZZO, Marlene; BERTONCELLO, Lígia; BENDER, Suzana. BIOCOSMÉTICO OU COSMÉTICO ORGÂNICO: REVISÃO DE LITERATURA. Revista Thêma et Scientia, $\quad$ v. $2, \quad$ n. 1 , jun./2012. Disponível em: https://www.fag.edu.br/upload/arquivo/1362061231.pdf. Acesso em: 10 dez. 2019. 